\title{
The Inclusivism of Religious Figures Amid a Plurality of Beliefs
}

\author{
Eko Kurniasih Pratiwi ${ }^{1}$, Nasitotul Janah ${ }^{2}$, Fahmi Medias ${ }^{3}$ \\ \{ekokurniasihpratiwi@ummgl.ac.id ${ }^{1}$ \} \\ Department of Sharia Islamics Law, Universitas Muhammadiyah Magelang, 56172, Indonesia ${ }^{1,2,3}$
}

\begin{abstract}
This study aims to determine the typology of religious figures in the theological aspect. This research used descriptive exploratory method by conducting in-depth interviews with non-Muslim religious leaders (Christians, Catholics, Hindus, Buddhists, and Confucians) related to five things, namely religious absolutism, religious authorianism practices, belief in the truth of the scriptures, beliefs in the truth of religious worship/rituals, and interfaith marriage. The results showed that the religious leaders had an absolute exclusive view in the theological aspect. The results of this study need to be juxtaposed with previous research on the inclusivism of religious leaders in political, social, and economic aspects. Previous research has found that religious leaders have inclusive views in non-theological aspects. For this reason, it can be concluded that religious figures have an inclusive typology. It is hoped that the understanding of religious inclusivism possessed by religious leaders can be transmitted to the respective religious communities to prevent horizontal conflicts in the name of religion.
\end{abstract}

Keywords: Inclusivism, Figure, Religion, Plurality

\section{Introduction}

Indonesia is a nation with a very diverse ethnic composition, which has diversity in potential, character, hobbies, education level, skin color, economic status, tendencies, and ideological affiliations, which are different. The pluralism of the Indonesian nation is also since almost all major religions, namely Islam, Protestantism, Catholicism, Hinduism, Buddhism, and Confucianism, live in this country. On the other hand, Indonesian society also consists of various ethnicities, cultures, and languages [1]. This kind of phenomenon, on the one hand, is a basic asset that can enrich positive religious dynamics, but the fact often proves that the various conflicts and social friction that have surfaced are triggered by these different beliefs [2].

The correct perspective and interaction of religious communities are an asset for the nation to support the success of the national development process; however, in the last two decades, the perspective of religion has developed as a source of conflict. Among the major cases, one that surfaced several years ago was the Poso case in Ambon, Sunni in East Java, GKI Yasmin in Bogor. The reality that occurs in Indonesia shows that the tension that occurs is closely related to factors that are within the scope of religion itself, namely the existence of truth claims and the doctrine of jihad [3]. Conflicts between religious communities that occur in Indonesia occur because of religious typology.

There are three typologies of religion, namely exclusive, inclusive, and pluralist. This understanding of diversity is usually contained in three dimensions of religion, each of which 
has an influence on a person's attitude. The three dimensions in question are the first, the theological dimension, where a person is religious according to his/her beliefs which have implications for his/her worship. Second, the social dimension, where a religious person is based on attitudes towards other religions and interactions between religious communities. Third, the political dimension, which is related to the leadership of other religions in an area as well as views on public policies conveyed by other religions [4][5].

\subsection{Exclusivism}

Religious exclusivity is teachings that teach privileges, excellence, and the spirit of dominating one religion over another. This spirit is shared by all religions. Some religious adherents in Indonesia sometimes bring up anti-multiculturalism, which is described by selfrighteousness, which is negative thoughts towards adherents of other religions. This group has an arrogant attitude that believes that its group is superior to others. Expressions of the diversity of this group, either its understanding, attitudes, or behavior tend to be closed, conservative, fundamentalist, extremist, intolerant, apological, and dogmatic, so that it is less conducive to seeing other religions in a friendly manner, and to accentuate the side of differences by covering up the sides of the similarities [6].

\subsection{Inclusivism}

Inclusive theology is a religious view that assumes that, outside of one's religion, there are truths from God. Substantially, inclusive religious understanding means believing that all the truths of other religions also exist in our religion. Inclusive theology is intended to provide an understanding or insight that is open, flexible, and tolerant [3].

The word “inclusive' comes from English, which means up to or including [7]. This term is used to indicate a situation or attitude that views other groups as a part of or as included in the situation. Religious inclusivism does not give up the belief that religion itself is true. Inclusivism does not admit that all other religions are equally true, but it is called inclusivism because people accept that other people from other religions can also survive. Three main ideas are interrelated from inclusivism, namely; (1) the substance of faith and worship is more important than a formal and literal religious symbolism; (2) religious messages, which are eternal in essence and universal in their meaning, must always be reinterpreted by each generation of the people according to the context of the times at hand; and (3) absolute truth belongs only to God, so no one can be sure that their understanding of God's message is the truest, truer, or better than other people's understanding. This group emphasizes the importance of tolerance towards people of the same faith and between religious communities because religious differences are seen as universal human nature [8].

\subsection{Pluralism}

Religious pluralism is based on the assumption that all religions are paths that are equally valid towards the same God. So, according to this understanding, all religions are different paths to the same God. Or, they are the states, that religion is a human perception relative to God who is absolute, so that - because of its relevance - then every religious adherent should not claim or believe that his/her religion is truer or better than other religions; or claiming that only his/her religion is true. In fact, according to Charles Kimball, one of the characteristics of evil religion 
(evil) is a religion that has a claim to an absolute truth (absolute truth claim) for their religion $[2]$.

\section{Method}

This research was a descriptive-analytical study that began with a search for the latest references on inclusivism of religious figures that had been carried out by previous research. In the next stage, making of instruments was used to describe, test, and analyze data. The data obtained were then analyzed and discussed using related theories to determine the suitability of the prevailing theory and the findings in the field. Respondents and informants in this study were figures from the religions of Islam, Christianity, Catholicism, Hinduism, Buddhism, and Confucianism at Forum Kerukunan Umat Beragama (FKUB) Magelang Regency. This research was a series of research on religious typology. Previous research was aimed at analyzing the social dimensions (socio-economic and political aspects).

\subsection{Data collection instruments}

The data instruments used in this study were:

a. Questionnaire, which was used to collect data from informants related to several things that could be used to identify the religious typology of religious figures. The questionnaire presented to respondents was related to five things, namely religious absolutism, religious authorianism practices, belief in the truth of the scriptures, beliefs in the truth of religious worship/rituals, and interfaith marriage. The questionnaire was open, so that respondents were freer to convey information as it is.

b. 2. Forum Group Discussion, which was used to collect qualitative assessment data about each religious doctrine related to religious absolutism, religious authorianism practices, belief in the truth of the scriptures, beliefs in the truth of religious worship/rituals, and interfaith marriage.

\subsection{Data analysis}

After the data were collected (data collection) properly, they were then edited and sorted. Qualitative data were collected by questionnaire and FGD. The interactive data analysis model was possible when the researcher was in the field. After all, a descriptive analysis was carried out. The analysis process was carried out during the research in the field (within site, in the field) and after the field. Furthermore, data reduction was made based on the relevance and adequacy of information to explain the typology of religion in community leaders.

Data reduction in this research simplified and systematically arranged the data obtained. The results of data reduction were then presented in the form of data display. To present the data, narrative descriptions were used. The next step was to make conclusions and/or verifications. This analysis model considered the interactive relationship between the main components in the research process. Therefore, in this study, verification was carried out by looking back at the data reduction and data display, so that the conclusions were not deviated from the analyzed data. The flow is as follows on Figure 1. 


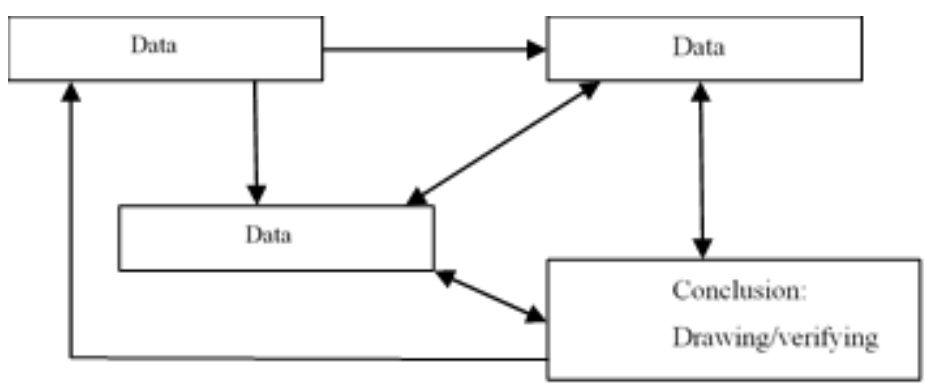

Fig. 1. Data analysis technique

The process of concluding this study was related to previous research as well as related to the perceptions of religious leaders on the socio-economic and political aspects that had been done previously.

\section{Results and Discussion}

\subsection{Religious absolutism}

Religious absolutism (truth and salvation) is a belief that truth and safety are only owned by one religion (the religion that is followed), while other religions are heretical. Besides, there are salvation claims that view that only one religion will enter heaven.

The results obtained show that all religious leaders have the belief that truth is not only owned by the religion they adhere to, but for each religious adherent, the religion he/she adheres to is the truest. Everyone decides to embrace religion because it is based on a personal belief that the teachings of his/her religion are true and guarantee his/her personal safety in the hereafter.

\subsection{Religious authoritarianism}

Authoritarianism is the practice that views religions other than the one a person adheres to as heretical, so that people of other religions must be saved by being converted/forced to embrace a certain religion. The results showed that the respondents acknowledged that their religion is a religion that carries the truth, but the truth itself does not only come from the teachings of their religion. There is only a slight difference in the religious concept of revelation/mission. Da'wah religious adherents have a religious mandate to convey their religious values to others. For this reason, as good people, the task of conveying divine mandates to others is an obligation that must be carried out, but there should be no form of coercion.

\subsection{Belief in the truth of the scriptures}

The Bible is a source of religious teachings that is used as a reference for religious people to practice religion themselves. The results showed that belief in the truth of the holy book is directly proportional to the belief of the religious community towards its religion. 


\subsection{Belief in the truth of worship}

Worship is an expression of worship of the people of a religion based on the teachings of the holy book. Every religion will believe that the way of worship is following the teachings of its respective religions.

\subsection{Marriage with different religions}

One of the sensitive issues when discussing relations between religious communities is related to interfaith marriages. The results showed that all religious leaders disagreed with the practice of interfaith marriage because it would raise several problems such as whose faith would become the standard in household life, whose faith the children would follow, which religious values would be instilled in children, asking for help from which religious leader if there is a conflict in the household, and whether each couple fully accepts the religion of his/her different partner.

\subsection{Discussion}

Overall, it can be emphasized that the level of respondents' confidence in the absolutism of religious truth is relatively high. This fact does not have to be interpreted negatively considering that the truth of theological elements, such as the principle of faith, must be believed in absolute black and white by the adherents. Even the firmness of the theological stance on the absolutism of truth is a necessity of faith, so that every adherent is not beset with doubts about the existence of his/her religious teachings. In a context like this, every religion always teaches the principle of the firmness of faith in the hearts of its adherents. Even in Islam, there is no tolerance in terms of the belief and position of the theologian [2]. Religion has a function as a guide and life guide for its adherents, for that the belief that the religion it adheres to is the most correct, the holy book, and it is the most correct way of worship are things that must be believed in the private sphere (internal to each individual and internal to certain religious people. ).

To know the inclusiveness of religious figures, it is necessary to look at two dimensions, namely the ideological dimension and the social dimension. Related research on the views of religious leaders in the social dimension, it has been shown that in the socio-economic and political aspects, religious leaders have an inclusive perspective. This means that in the process of social, economic, and political activities, they do not use religious standards as the main reference for partnering, and are more open to other religious communities [3][4][9].

\section{Conclusion}

The conclusion of this study is related to the results of previous studies. In the socioeconomic and political dimensions, religious leaders have an inclusive view. Meanwhile, in the ideological aspect, that is the focus of this research, religious leaders have an exclusive typology. If one conclusion is drawn, in general, religious figures have an inclusive religious typology (exclusive in the ideological dimension, but inclusive in the social dimension) 


\section{Acknowledgement}

This study was supported by the Ministry of Research, Technology and Higher Education of the Republic of Indonesia through the PDUPT programme. We want to extend appreciation to the Forum Kerukunan Umat Beragama, Pemuda Lintas Agama, and Universitas Muhammadiyah Magelang who have significanly contributed to this reseach.

\section{References}

[1] F. M. Yunus, F. Ushuluddin, U. Islam, and N. Uin, "Konflik Agama di Indonesia, Problem dan Solusi Pemecahannya," Substansia, vol. 16, pp. 217-228, 2014.

[2] A. Zamakhsari, "Teologi Agama-Agama Tipologi Tripolar: Eksklusivisme, Inklusuvisme dan Kajian Pliralisme,” Tsaqofah J. Agama dan Budaya, vol. 18, no. 1, pp. 35-51, 2020.

[3] A. Aziz, Eksklusivisme Beragama, Cetakan pe. Jakarta: Puslitbang Kehidupan Keagamaan Badan Litbang dan Diklat Kementerian, 2013.

[4] Z. Baidhawy, Pendidikan Agama Berdasarkan Multikulturalisme. Jakarta: Erlangga, 2005.

[5] Z. Abidin, "Teologi Inklusif Nurcholish Madjid: Harmonisasi Antara Keislaman, Keindonesiaan," Humaniora, vol. 5, no. 2, pp. 665-684, 2014.

[6] M. Zamzani, "Hikmah dalam Al-Qur'an dan Implementasinya dalam Membangun Pemikiran Islam yang Inklusif,” Teosof. J. Tasawuf dan Pemikir. Islam, vol. 6, pp. 355-382, 2016.

[7] W. Khozin, "Sikap keagamaan dan potensi radikalisme agama mahasiswa perguruan tinggi agama," Edukasi, vol. 11, no. 6, pp. 289-304, 2013.

[8] E. K. P. Nasitotul Janah, Fahmi Medias, "The intention of religious leaders to use Islamic banking services: the case of Indonesia,” J. Islam. Mark., vol. 1, 2020.

[9] E. K. Pratiwi, F. Medias, and N. Janah, "Perception of Non-Muslim Religious Leaders to Islamic Financial Institutions," vol. 436, pp. 893-896, 2020. 